\title{
Covid-19 Salgınının TR71 Düzey 2 Bölgesinde İşgücü Piyasasına Etkileri
}

\author{
Nazan ŞAHBAZ KILINÇ
}

\section{Öz}

\begin{tabular}{c} 
Makale Türü \\
Araştırma Makalesi \\
Başvuru Tarihi \\
16.05.2021 \\
Kabul Tarihi \\
17.09.2021 \\
Dol \\
\hline $10.53306 /$ klujfeas.937763
\end{tabular}

Covid-19 salgınıyla mücadele edebilmek ve kontrol altına alabilmek için ülkelerin çoğu birbirine benzer önlemler almaktadır. Özellikle geçici karantina uygulamaları, seyahat kısıtlamaları, sosyal mesafe kuralları, belli sektörlerdeki işletmelerin geçici olarak faaliyetlerine kıııtlama getirilmesi veya ara verilmesi gibi alınan sıkı tedbirler işgücü piyasasında olumsuz sonuçlara yol açmıştır. Çalışmada, tüm dünyada etkilerinin derinden hissedildiği ve sağık kriziyle birlikte ekonomik krize dönüşen Covid-19 krizinin hem Türkiye genelinde hem de TR71 düzey 2 bölgesinde işgücü piyasasını nasıl etkilediği işsizlik, işgücüne katıım, istihdam oranları ve işsizlik ödeneğine ait şekiller ve grafikler yardımıyla açıklanmıştır. Bu çalışma, işgücü piyasasına ait değişkenler ışı̆̆ında Covid-19 salgınının istihdam üzerindeki olumsuz etkilerini ortaya koymaktadır. Çalışmada kullanılan veriler incelendiğinde, özellikle işgücüne katılım ve istihdam oranlarındaki düşüşler açıkça görülmektedir. Ayrıca pandemi döneminde hem Türkiye genelinde hem de TR71 düzey 2 bölgesinde işsizlik ödeneğine başvuruların özellikle 2020 Nisan ayında yoğunlaştığı dikkat çekmektedir.

Anahtar sözcükler: Covid-19, işgücü piyasası, şşsizlik, TR71 Düzey 2 Bölgesi, istihdam tedbirleri, işsizlik ödeneği

1 Dr. Öğr. Üyesi, Kırıkkale Üniversitesi, I.İ.B.F., İktisat Anabilim Dalı, nkilinc@kku.edu.tr, ORCID: 0000-0003-19563965 


\title{
Effects Of Covid-19 Outbreak On Labor Market In TR71 Region
}

\author{
Nazan ŞAHBAZ KILINÇ²
}

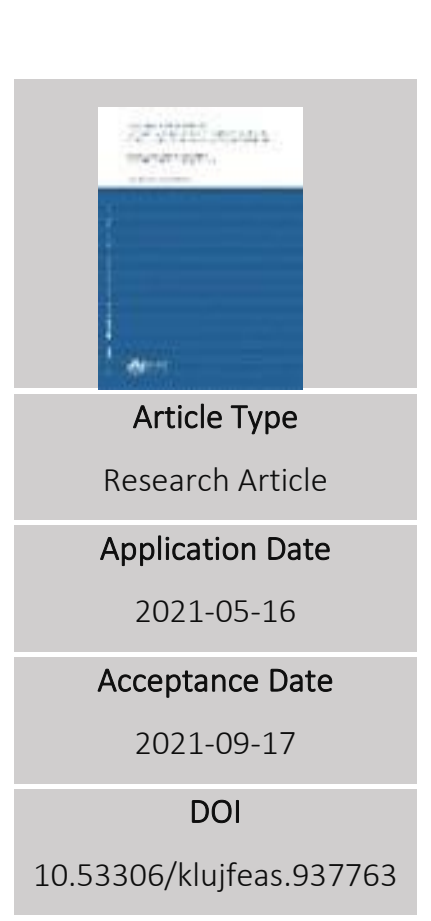

\begin{abstract}
Most countries take similar measures to combat and control the Covid-19 break. In particular, measures such as temporary quarantine practices, travel restrictions, social distance rules and temporary restrictions or suspensions of businesses in certain sectors have resulted in negative consequences in the labor market. In the study, it was explained with the help of graphs how the Covid19 crisis, whose effects were deeply felt all over the world and turned into an economic crisis with the health crisis, affected the labor market both in Turkey and in the TR71 region. Additionally the study differs from other studies because it examines Turkey and TR71 comparatively. When the data used in the study are examined, the decreases in labor force participation and employment rates are clearly seen. In addition, during the pandemic period, applications for unemployment benefits intensified both in Turkey and in the TR71 level 2 region, especially in April 2020.
\end{abstract}

Key words: Covid-19, labor market, TR71, employment measures, unemployment benefit

2 Assist. Prof., Kırıkkale University, I.I.B.F., Department of Economics, nkilinc@kku.edu.tr, ORCID: 0000-0003-19563965 


\section{Giriş}

Koronavirüs, 2019 yılının sonlarına doğru ilk olarak Çin'in Wuhan kentinde ortaya çıktığında, virüsün küresel çapta bu hızla yayılacağını kimse hesaba katmamıştı. Dünya Sağıık Örgütü’nün 11 Mart 2020'de Covid-19 salgınını pandemi ilan etmesiyle birlikte, pek çok ülke kendi dinamiklerine göre kısıtlama önlemleri almaya başlamıştır. Covid-19 salgını dünya genelinde sağlık krizi olarak ortaya çıkmasına rağmen, ilerleyen dönemde bu salgın küresel düzeyde ekonomik krize dönüşmüştür ve bu krizin ne kadar süreceği tam olarak bilinmemektedir.

Tüm dünya Covid-19 salgınından büyük bir darbe yemiştir. Fabrikaların yarı zamanlı veya tamamen kapanmasıyla üretime ara verilmiş, petrol fiyatlarında sert düşüş yaşanmış, uluslararası hisse senedi ve emtia fiyatları hızlı bir şekilde düşüş trendine geçmiş, turizm gelirleri azalmış, sınırların kapatılması ve seyahat kııtlamaları gibi uygulamalardan dolayı havayolu, deniz ve kara taşımacılığı zarar görmüş ve dünya genelinde milyonlarca kişi işsiz kalmıştır (www.thinktech.stm.com.tr, 15.01.2021). Covid-19 salgını, tüm ekonomileri ve tüm dünya bölgelerindeki işgücü piyasalarını ciddi şekilde bozmuştur. Gençler iş bulmadaki daha büyük güçlüklerin yanı sıra eğitim-öğretimin, istihdamın ve gelirin kesintiye uğraması gibi çok sayıda şok yaşamaktadırlar. Yaşanan iş kesintilerinden en çok etkilenen kesimler kalifiye olmayan işgücü, serbest meslek sahipleri, imalat ve hizmet sektörlerinde çalışanlar, gençler ve kadınlar olmuştur (www.ilo.org, 18.12.2020).

Salgını kontrol altına alabilmek için Türkiye'de alınan önlemler arasında AVM'lerin kapatılması, restoran, lokanta ve kafelerin sadece paket servis yapmasına izin verilmesi, sınırların kapatılması, yüz yüze eğitime ara verilip uzaktan eğitime geçilmesi, şehirlerarası seyahat kısıtlaması ve hafta sonu sokağa çıkma yasağı gibi uygulamalar yer almıştır. Bu uygulamaların hepsi birçok sektörü olumsuz etkilemiş ve ülke genelinde işgücüne katılım oranının düşmesine ve işsizlik oranının artmasına neden olmuştur (www.aa.com.tr, 18.11.2020).

Pandemi döneminde tam kapanma uygulamasından dolayı çoğu ülkede İşyerlerinin kapanması sebebiyle özellikle hizmet sektöründe çalışanların büyük bir kısmı işini kaybetmiştir. Bu bağlamda küresel çapta azalan toplam talebe karşı önlem alabilmek için, uluslararası kuruluşlar tarafından ülkelere yönelik yardım ve destek programları uygulanmaya başlanmıştır. Örneğin, IMF COVID-19 salgınının ekonomik etkilerini derinden hisseden 80 ülkeye mâlî yardım ve borç servisi yardımı gerçekleşmiştir. 2 Eylül 2020 tarihi itibariyle yardım miktarı 87,9 milyar ABD Dolara ulaşmıştır (www.imf.org, 12.09.2020).

TR71 düzey 2 bölgesi Kapadokya ve Hacı Bektaş-ı Veli gibi kültürel değerleri barındırdığı için turizm açısından zengin bir yapıya sahiptir. Ayrıca TR71 düzey 2 bölgesinde doğa turizmi, termal ve sağlık turizmi, kültür turizmi, balon turizmi, inanç turizmi aktif olarak yapılmaktadır. Geleneksel el sanatları dışında toprak kap, halıcılık, dericilik, çömlekçilik, çinicilik, sele sepeti, ebru ve seramikçilik halen esnaf ve sanatkarlar sayesinde varlığını sürdürmekte ve üretilen ürünler turistik amaçlarla pazarlanabilmektedir (AHIKA, 2016, s. 15). Bu bahsedilen faktörlerden dolayı TR71 bölgesinde hizmet sektörünün öne çıktığı ve Covid-19 salgınının da ağılıklı olarak hizmet sektörünü etkilediği için çalışmada TR71 düzey 2 bölgesi incelenmiştir. 
TÜik ve IŞKUR'a ait veriler ve tahminlerden yararlanılarak hem Türkiye ekonomisinin hem de TR71 düzey 2 bölgesinin işgücü piyasası incelenmiştir.

Çalışma TR71 düzey 2 bölgesinin işgücü piyasasına ait temel göstergeler ışığında Covid-19 salgınının yarattığı etkileri ortaya koymak için hazırlanmıştır. Hem Türkiye hem de TR71 düzey 2 bölgesine ait işgücü piyasasına ait veriler ele alındığında, pandeminin olumsuz etkileri açıkça görülmektedir. Ayrıca pandemi döneminde hem Türkiye hem de TR71 düzey 2 bölgesinde işsizlik ödeneğine başvuranların özellikle 2020 Nisan ayında yoğunlaştığı dikkat çekmektedir. Çalışmanın birinci bölümünde, Covid-19'un istihdama etkileriyle ilgili yapılan çalışmalar özetlenmiştir. Ikinci bölümde, TR71 düzey 2 bölgesindeki istihdam yapısı ve işgücü detaylı olarak ele alınmıştır. Üçüncü bölümde, Türkiye' de istihdam ve işgücü göstergelerinin gelişimi, dördüncü bölümde Türkiye ve TR71 düzey 2 bölgesi cinsiyete ve yaş gruplarına göre istihdam yapısı ve işgücüne ait gelişmeler ve beşinci bölümde ise Türkiye ve TR71 düzey 2 bölgesine ait işsizlik ödeneği başvuruları şekiller yardımıyla ortaya konulmuştur. Son bölümde ise genel bir değerlendirme yapılmış ve bu konuyla ilgili yapılması gerekenlere değinilmişitir.

\section{Literatür}

Covid-19 salgınının hem küresel çapta hem de ulusal düzeyde olumsuz etkileri mevcuttur. Salgınının bu olumsuz etkilerini araştıran çok sayıda çalışma mevcuttur. Bu konuyla ilgili yapılan çalışmalar aşağıda özetlenmiştir.

Bell vd. (2020), çalışmalarında Mart 2020'de Covid-19 krizinin başlamasından 2020'nin sonlarına kadar Kaliforniya'daki işgücünün yaklaşık \%45'inin işsizlik sigortası ve işsizlik yardımına başvurduğuna dikkat çekmişlerdir. Eyalet tarihinde benzeri görülmemiş bir işgücü piyasası krizi olduğunu vurgulamışlardır.

Bulut ve Pınar (2020), çalışmalarında Türkiye'de Covid-19 önlemlerinin en üst seviyede olduğu Nisan ile Eylül ayları arasındaki dönemde TÜik'in yayınlamış olduğu istihdam verilerini karşılaştırarak, Covid-19'un istihdam üzerindeki etkilerini analiz etmişlerdir. Ayrıca, Türkiye'de istihdama yönelik alınan tedbirler ve teşviklere de detaylı olarak değinilmiştir.

Cortes ve Forsythe (2020), çalışmalarında Covid-19 salgınının istihdam üzerindeki etkilerini ele almışlardır. ABD'deki mevcut nüfus araştırmasının stok ve akım verilerini de hesaba katarak salgının var olan eşitsizlikleri daha da kötüleştirdiğine değinmişlerdir. İstihdam kayıplarının yaygın olmasına rağmen, daha düşük ücretli mesleklerde ve endüstrilerde büyük ölçüde olduğuna dikkat çekmişlerdir. Hispanikler, daha genç işçiler, daha düşük eğitim seviyesine sahip olanlar ve kadınlar gibi dezavantajlı gruplardan oluşan bireylerin iş kayıplarının daha fazla olduğunu tespit etmişlerdir.

DiKA (2020), yayınladıkları raporda pandemi döneminde üniversiteli işe yerleştirmelerinde Siirt harici diğer illerde genel bir düşüş olduğuna, Mardin ve Batman illerinde genç kesimin pandemi dönemi işe yerleştirmelerinde keskin azalmaların yaşandığına dikkat çekmiştir. Ayrıca, bu bölgedeki kadınların işe yerleştirilmelerindeki düşüşlerin 2020 Nisan ve Mayıs aylarında alınan önlemler, karantina uygulamaları ve faaliyetini durduran işletmelerden kaynaklandığına değinmiştir. 
Forsythe vd. (2020), çalışmalarında iş açıklığı, işsizlik sigortası, ilk talepler ve geleneksel istihdam verilerini Covid-19'un işgücü piyasası üzerindeki etkisini araştırmak için kullanmışlardır. Mart ayının ikinci yarısında iş ilanlarının çöktüğünü, Nisan sonunda ise \%40'ın üzerinde bir düşüş yaşandığını ifade etmişlerdir. Bu çöküşün ABD’nin eyaletlerinde geniş tabana yayıldığını, neredeyse tüm endüstrilerde, mesleklerde ve görevlendirmelerde daralma görüldüğüne değinmişlerdir. Mevcut kriz sırasında en çok talep gören perakende sektörün en az darbeyi aldığını, eğlence ve konaklama sektörlerinin ise en büyük çöküşü yaşadığından bahsetmişlerdir.

Hall ve Kudlyak (2020), çalışmalarında pandeminin ABD’nin işgücünde önemli bir düşüşe neden olduğunu ve işsizliğin ve nüfusun işgücü piyasası dışındaki genişlemesine istihdamdaki daralmanın eşlik ettiğini ifade etmişlerdir. ABD'de 2020'nin Şubat Ayında çalışma çağındaki nüfusun \%36,6'sı ne çalışıyor ne de işsiz olarak gözüktüğünü ve Kasım ayında işgücü dışı payın 1,9 puan artarak \%38,5’e çıktığını belirtmişlerdir. Durgunluklarda işgücü dışındaki nüfus artışı nadiren bu kadar fazla olduğuna ve 2008 küresel finans krizinin yaşandığı dönemde dahi işgücü dışı payın sadece 0,3 puan arttığına dikkat çekmişlerdir.

Kara (2020), çalışmasında Covid-19 pandemisinin çalışma hayatına olan etkisini; bu dönemde evden çalışmanın giderek yaygınlaşmasıyla kimlerin uzaktan işgücüne dahil olabileceği konusunda son dönemde yapılan araştırmaları dikkate alarak özetlenmiştir. Buna ek olarak çalışmada, bu salgının işgücü piyasasına olan olumsuz etkilerini azaltmak için hükümetlerin ele aldıkları olağanüstü istihdam önlemlerine yer verilmiş ve çeşitli ülkelerde uygulanan önlemler karşılaştırılmıştır.

Koca (2020), çalışmada Türkiye'nin işgücü piyasasına ait unsurlar detaylı olarak ele alınarak, işgücü piyasası yapısında ortaya çıkan sorunların çözümüne yönelik oluşturulan mekanizmalar incelenmiştir. Ayrıca çalışmada Covid-19 salgınıyla birlikte işgücü piyasasında yaşanan değişimler ve alınan önlemlere vurgu yapılmıştır.

Uysal vd. (2020), çalışmalarında Türkiye'de Tüik tarafından düzenli olarak açıklanan işgücü istatistiklerinin tanımları özetlemiş, Covid-19 salgınının bu istatistiklere olan ve olması muhtemel olumsuz etkileri açıklamışlardır. Çalışmalarında Aralık 2019'dan bu yana işgücü ve istihdamın birbirlerine paralel olarak düştüğünü vurgulamışlardır. Ayrıca son istatistiklere göre Ocak döneminden Şubat dönemine istihdamın 495.000'e, işgücünün ise 562.000'e gerilediğine değimmişlerdir.

Su vd. (2021), çalışmalarında Covid-19 salgınının Almanya, İtalya, İspanya, İngiltere ve Fransa ekonomilerinde işsizlik üzerindeki etkilerini incelemeyi amaçlamışlardır. Bu amaçla 2019 Aralık ve 2020 Aralık dönemini dikkate alarak Fourier nedensellik testini kullanmışlardır. Z testi sonuçlarına göre, Covid-19 vakaları Almanya, İtalya ve İngiltere de işsizliğe neden olmuştur.

Pandemi döneminde sadece Türkiye değil, tüm dünya önemli olumsuz etkilerle karşı karşıya kalmıştır. Bu etkilerin özellikle işgücü piyasası açısından da ele alınması ayrı bir öneme sahiptir. Ayrıca çalışma hem Türkiye hem de TR71 düzey 2 bölgesini karşılaştırmalı olarak ele aldığı için literatürde yer alan çoğu çalışmadan bu noktada farklılaşmaktadır. 


\section{TR71 Düzey 2 Bölgesi Genel İstihdam Yapısı ve İşgücü}

Birçok ülkede bölgeler arası gelişmişlik farkları söz konusudur. Bu bağlamda bölgeler ile ilgili detaylı veri ve göstergelere sahip olmak politika tasarımı sürecinde büyük önem taşımaktadır. İ̧gücü piyasasına ilişkin bölgesel bir politika oluşturulurken, işgücü haraketliliğine ilişkin verilerin de dikkate alınması gerekmektedir. Aksi takdirde, tasarlanan politika yeterli etkililik düzeyine ulaşamamaktadır (OECD, 2020).

TR71 düzey 2 bölgesinin istihdam yapısı ve işgücünün genel yapısı şu şekildedir:

- Bölgede sadece tarım faaliyetlerinin değil sanayi yatırımları talebinin de fazla olması

- Bölgedeki Niğde, Aksaray, Nevşehir gibi illerin geçmişten ve özellikle tarımdan gelen zenginliğe sahip olması

- Bölgedeki illerde eğitim düzeyinin yüksek olması

- Bölgedeki illerin bazılarında büyük firmaların kadın istihdamına uygun olması nedeniyle kadın işgücünü çekme potansiyeline sahip olması

- Bölgenin inanç ve yayla turizmine uygun altyapısının olması (Progem, 2013, s. 199).

TR71 Düzey 2 Bölge illerinden bazılarında büyük firmalar (Mercedes Benz, Petlas, Tüpraş, Tat, Doğuş, Sütaş, MKE ) vardır. Bu firmalar bulundukları illerde oldukça önemli istihdam olanakları ve katma değer yaratmaktadır. Bu tür büyük şirketler yan sanayii ürünlerine olan talebi arttırmakta ve bölge ekonomisine katkı sağlamaktadır (AHIKA, 2016, s. 625).

\section{Türkiye'de İstihdam ve İşgücü Göstergelerinin Gelişimi}

Mevcut ekonomik sistem ve yakın gelecek bakımından işgücü ve bu işgücünün niteliği, yaş ve cinsiyete göre dağılımı, eğitimi, istihdamı, işsizliği gibi unsurlar büyük öneme sahiptir. Türkiye'de işgücü piyasaları ele alındığında, kriz dönemleri dışında işgücünde yıllar itibari ile artış yaşandığı görülmektedir (Kalkınma Bakanlığı, 2014, s. 32). Türkiye'de istihdam ve işgücü verileri şekiller yardımıyla gösterilmektedir. 
Şekil 1. Türkiye Ekonomisinde İstihdam ve İşgücü (Bin Kişi)

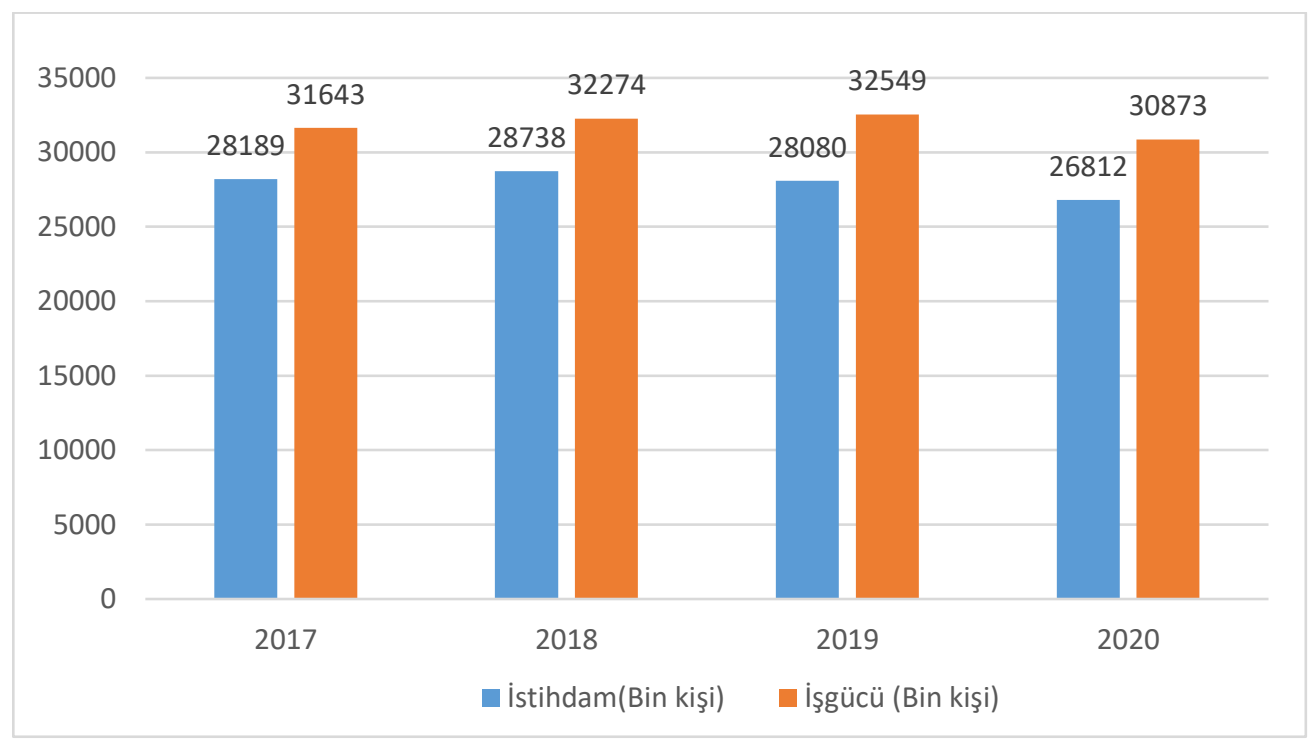

Kaynak: Tüik, İşgücü İstatistikleri

Türkiye'de istihdam edilenlerin sayısı 2019 yılında bir önceki yıla göre 658 bin kişi azalarak 28 milyon 80 bin kişi olarak gerçekleşmiştir. İşgücünün ise 2019 yılında bir önceki yıla göre 275 bin kişi artarak 32 milyon 549 bin kişi olduğu görülmektedir. 2020 yılında ise hem işgücü hem de istihdam da ciddi ölçüde azalma olduğu dikkat çekmektedir. 2020 yılında 2019 yılında 28 milyon 80 bin kişi olan istihdam yaklaşık \%5 azalırken işgücü yaklaşık \%6 azalmıştır. 
Şekil 2. Türkiye Ekonomisinde İşsizlik, İşgücüne Katılım ve İstihdam Oranları

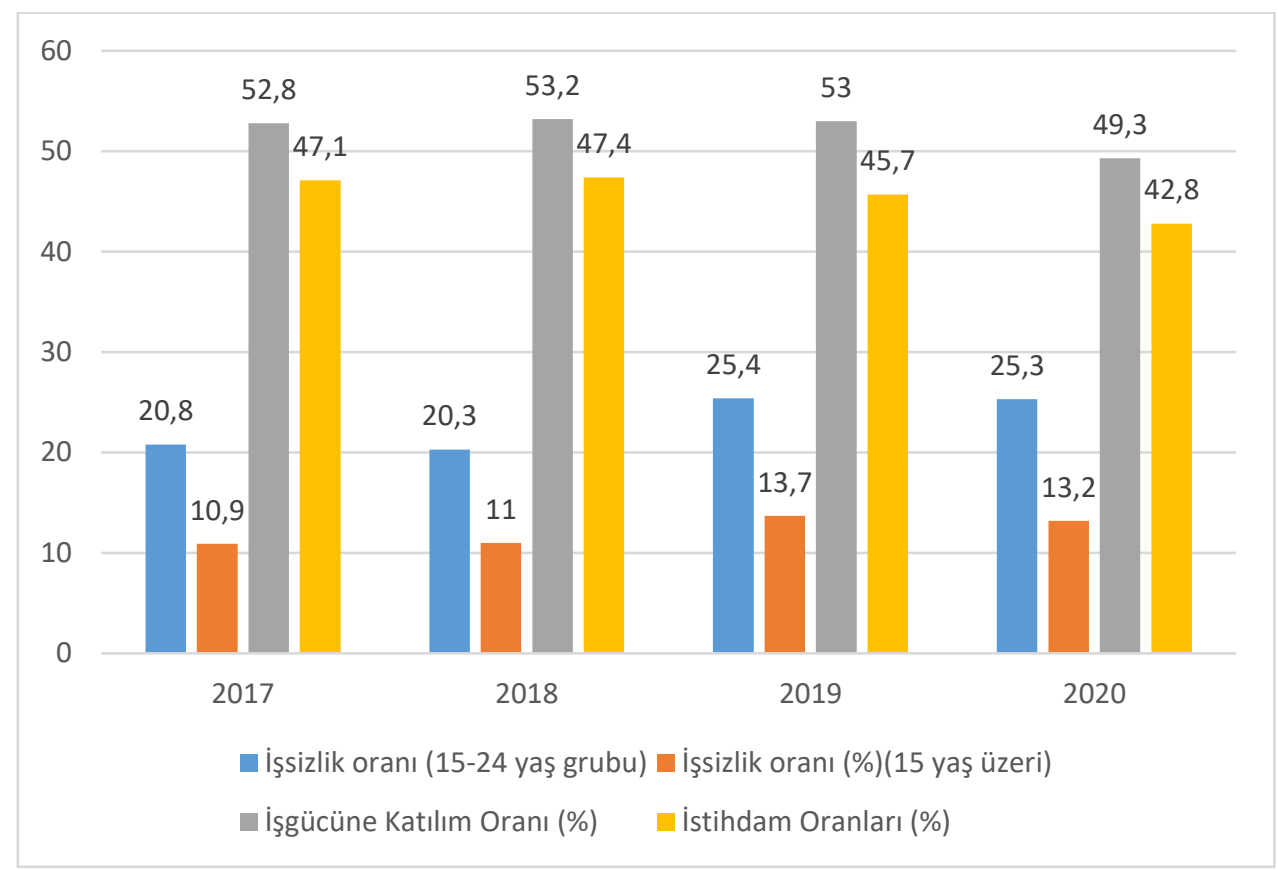

Kaynak: TÜik, İşücü İstatistikleri

Türkiye genelinde 2019 yılında işsizlik oranı \%13,7 düzeyinde gerçekleşmiştir. 2019 yılında bir önceki yıla göre işsizlik oranının 2,7 puan arttığı dikkat çekmektedir. 2019' da işgücüne katılma oranı ise \%53,0 olarak gerçekleşmiştir. 2019 yılında işgücüne katılma oranında ise 0,2 puanlık azalış görülmektedir. 2019 yılında istihdam oranı \%45,7 seviyesinde gerçekleşmiştir. 2019 yılında istihdam oranının bir önceki yıla göre 1,7 puan azaldığı görülmektedir. Covid-19'un etkilerinin hissedildiği 2020 yılında ise 15-24 yaş grubunda işsizlik oranında önemli bir değişme yaşanmadığı, 15 yaş üzerinde ise işsizlik oranında 0,4 puan azalma yaşandığı dikkat çekmektedir. Buna karşın işgücüne katılma oranında 3,7 puan istihdam oranında ise 2,9 puan azalma gerçekleşmiştir.

TÜik 2021 yılında işgücü istatistiklerinde revizyona gideceğini açıklamıştı. Avrupa Birliği ülkeleri ile eş zamanlı olarak; ILO'nun kararlarına ve bununla ilgili AB tüzüğüne uyum sağlamak için yeni düzenlemelere geçilmiştir. Üçer aylık hareketli ortalamalar olarak aylık yayımlaman işgücü istatistikleri 2021 Ocak ayından itibaren bağımsız aylık olarak yayımlanmaktadır. Ayrıca Tüik haber bültenlerinde açıkladığı verileri mevsim etkisinden arındırılmış olarak vermeye başlamıştır (TÜik, 2020). TÜiK Kasım 2020'ye kadar açıkladığı bültenlerinde mevsim etkisinden arındırılmamış veriyi vurgularken, yeni düzenlemeyle birlikte artık mevsim etkisinden arındırılmış veriyi öne çıkarmaktadır. Bu bağlamda yeni açıklanan verilerde işgücüne katılım oranı ve istihdam oranında azalma yaşanırken, işgücü 
oranında da azalma olduğu dikkat çekmektedir. Ayrıca kişilerin bu dönemde ümitsizliğe kapılarak artık iş aramaktan da vazgeçmesinin etkisi olması muhtemeldir. Covid-19 salgınının da etkisiyle işgücü piyasasına dahil olamayanlar arttıkça buna paralel olarak istihdam edilen ve işsiz sayısında da azalma meydana gelmektedir.

Şekil 3. Türkiye'de İktisadi Faaliyet Kollarına Göre İstihdam Edilenler (15+ Yaş)

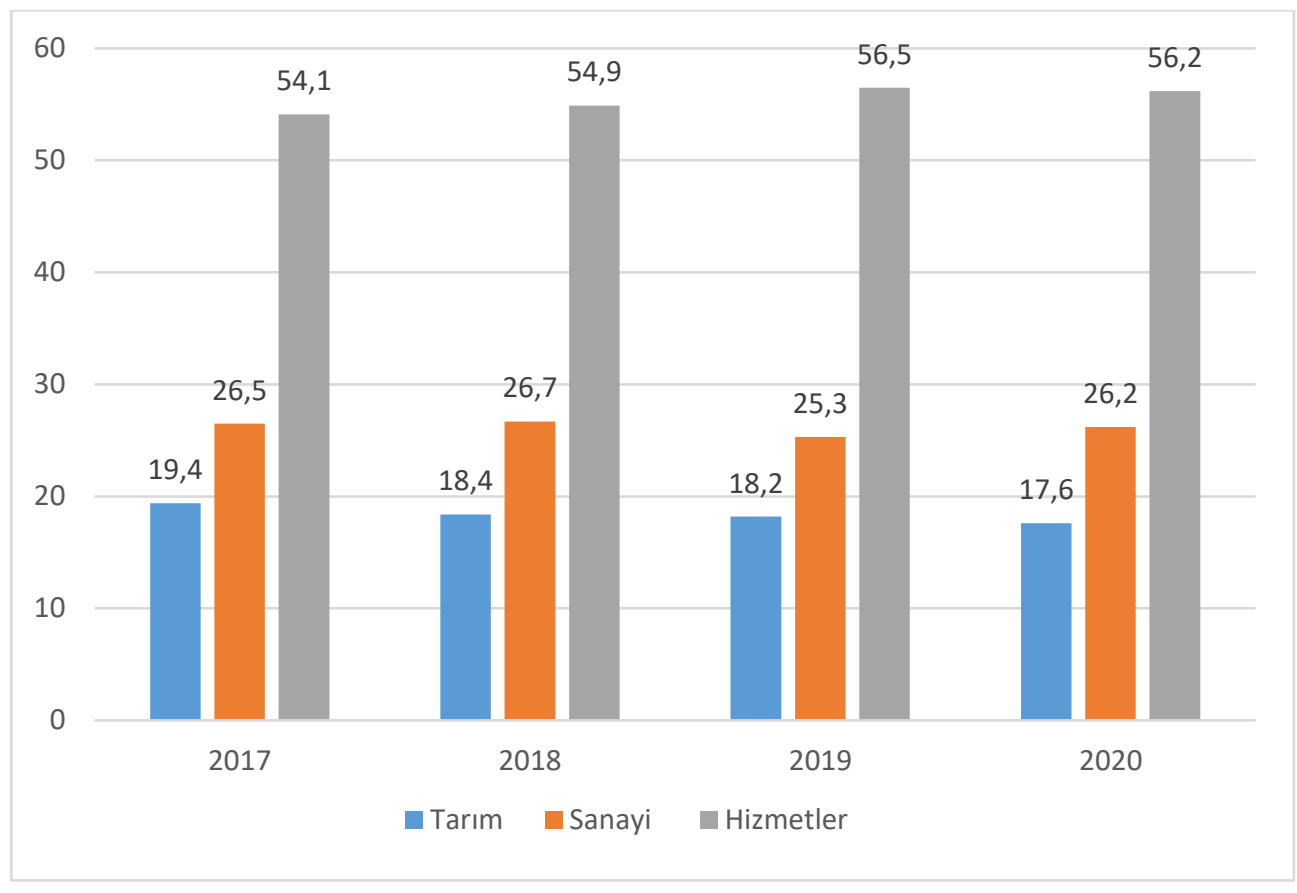

Kaynak: Tüik, İşücü İstatistikleri

Şekil 3.'te yer alan iktisadi faaliyet kollarına göre istihdamın dağılımı dikkate alındığında 2019 yılında istihdam edilenlerin yaklaşık \%18,2'i tarım sektöründe, \%25,3'ü sanayi sektöründe ve \%56,5’i de hizmetler sektöründe çalışmaktadır. Bu oranlar bir önceki yıl ile karşılaştırıldığında tarım ve sanayinin payının azaldığı hizmetler sektörünün payının arttığı görülmektedir. 2020 yılında sektörel dağılım incelendiğinde tarım ve hizmetler sektöründeki istihdamın azaldığı, sanayi sektöründe ise arttığı dikkat çekmektedir. Tarım sektöründe istihdam edilenlerin 2019 yılına göre 0,6 puan, hizmetler sektöründe ise 0,3 puan azaldığı, sanayi sektöründe istihdam edilenlerin ise 0,9 puan arttığı görülmektedir. 


\section{Türkiye ve TR71 Düzey 2 Bölgesi Cinsiyete ve Yaş Gruplarına Göre İstihdam Yapısı ve İşgücü}

Türkiye'de işgücünün cinsiyet olarak dağılımında erkek işgücünün her zaman kadın işgücüne kıyasla önemli bir ağılığa sahip olduğu görülmektedir. Ayrıca 2030'lu yıllara doğru genç nüfusta azalış orta yaş ve üzeri yaş grubunda ise yığılmaların olacağı öngörülmektedir (Kalkınma Bakanlığı, 2014, s. 32-34).

Şekil 4. Türkiye'de Cinsiyete Göre İşsizlik, İşgücüne Katılım ve İstihdam Oranları (\%)

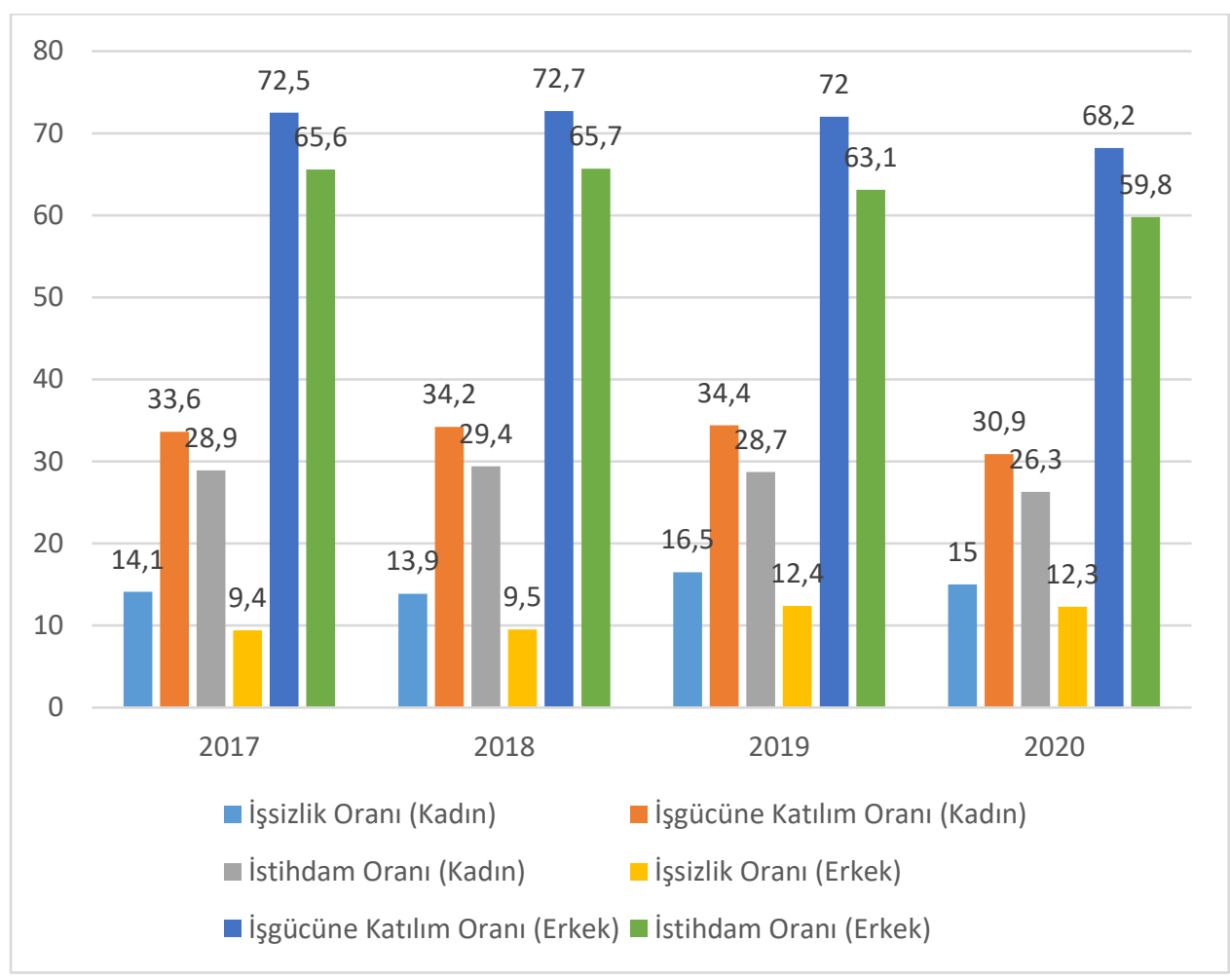

Kaynak: Tüik, İşgücü İstatistikleri

Şekil 4. incelendiğinde, kadın ve erkek arasında işgücüne katılım ve istihdam oranlarında önemli farklılıklar olduğu görülmektedir. 2017, 2018 ve 2019 yıllarında erkek işsizlik oranı sürekli artmış ancak son dört yılda kadın işsizlik oranı ise dalgalanma göstermiştir. Son üç yılda ise, erkek ve kadın istihdam oranının sürekli azaldığı dikkat çekmektedir. Pandeminin olduğu dönemi daha detaylı ele aldığımızda, işgücüne katılım, istihdam ve işsizlik oranlarında her iki cinsiyette de düşüş olduğunu, özellikle kadınların işgücüne katılım ve istihdam oranlarında 
yaklaşık 4 puan azalmanın yaşandığı görülmektedir. Bu durum pandeminin işgücü piyasasında kadınları daha çok olumsuz etkilediğini göstermektedir.

Şekil 5. Yaş Gruplarına Göre Türkiye'de İşsizlik, İşgücüne Katılım ve İstihdam Oranları (\%)

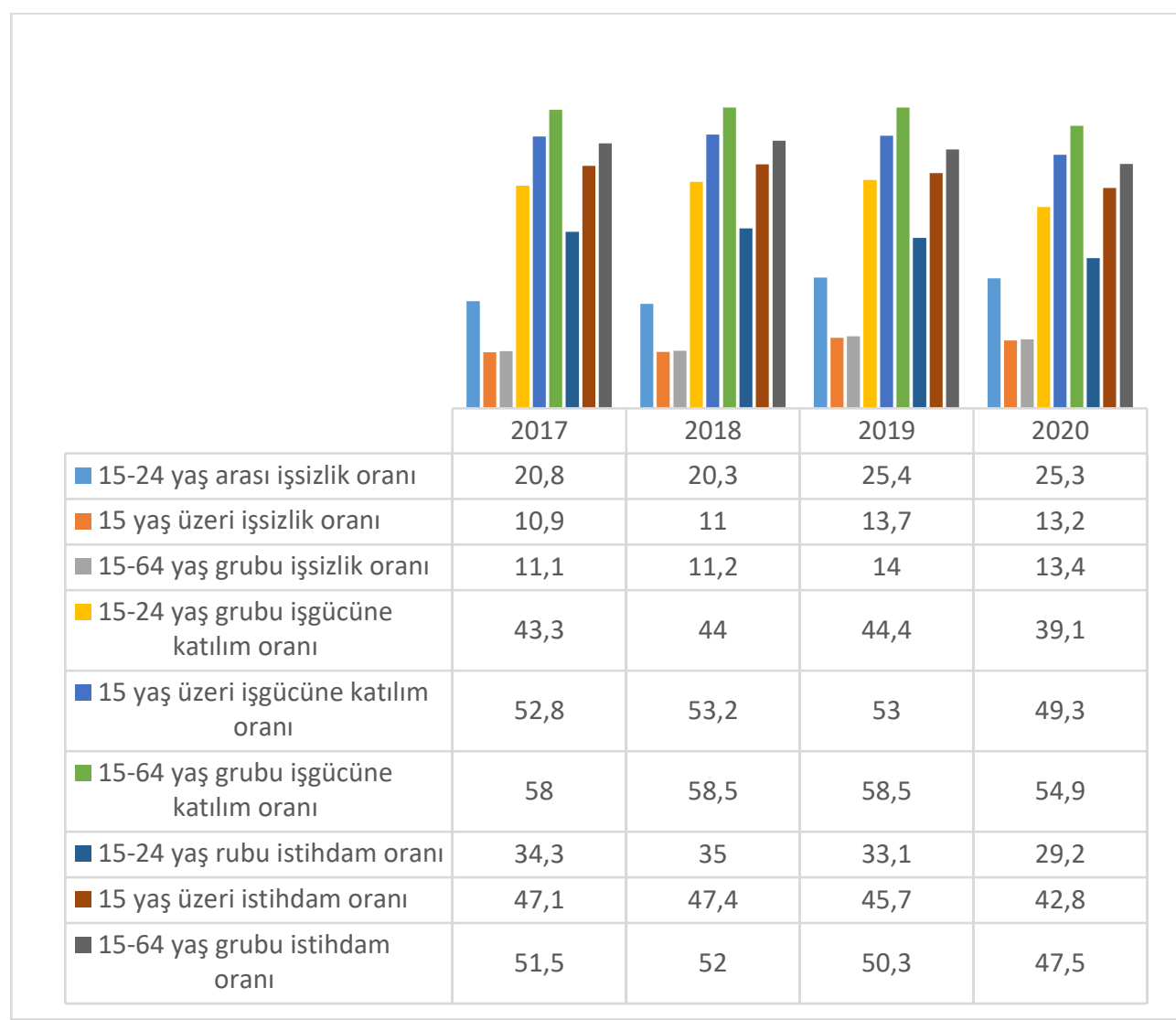

Kaynak: Tüik, İşgücü İstatistikleri

Şekil 5.'te özellikle 2019 yılında Türkiye'de 15-24 yaş grubu işsizlik oranının bir önceki yıla göre yaklaşık 5 puan artış gösterdiği, ancak 2020 yılında ise az da olsa azaldığı gözlemlenmektedir. İşsizlik oranındaki bu azalışa rağmen 2020 yılında işgücüne katılım ve istihdam oranlarının her yaş grubunda önceki yıllara göre önemli ölçüde düştüğü görülmektedir. Özellikle 2020 yılında 15-24 yaş grubunda işgücüne katılım oranında 5 puandan fazla azalma yaşanmıştır ve yine aynı yaş grubunun istihdam oranında da yaklaşık 4 puanlık düşüş gerçekleşmiştir. Türkiye'de gençlerin istihdam edilmesiyle ilgili sorunlar zaten yıllardır süre gelmektedir. Ancak pandeminin de etkisiyle bu durumun daha da kötüye gittiği açıkça görülmektedir. 
Şekil 6. TR71 Düzey 2 Bölgesinde İstihdam ve İşgücü (Bin Kişi)

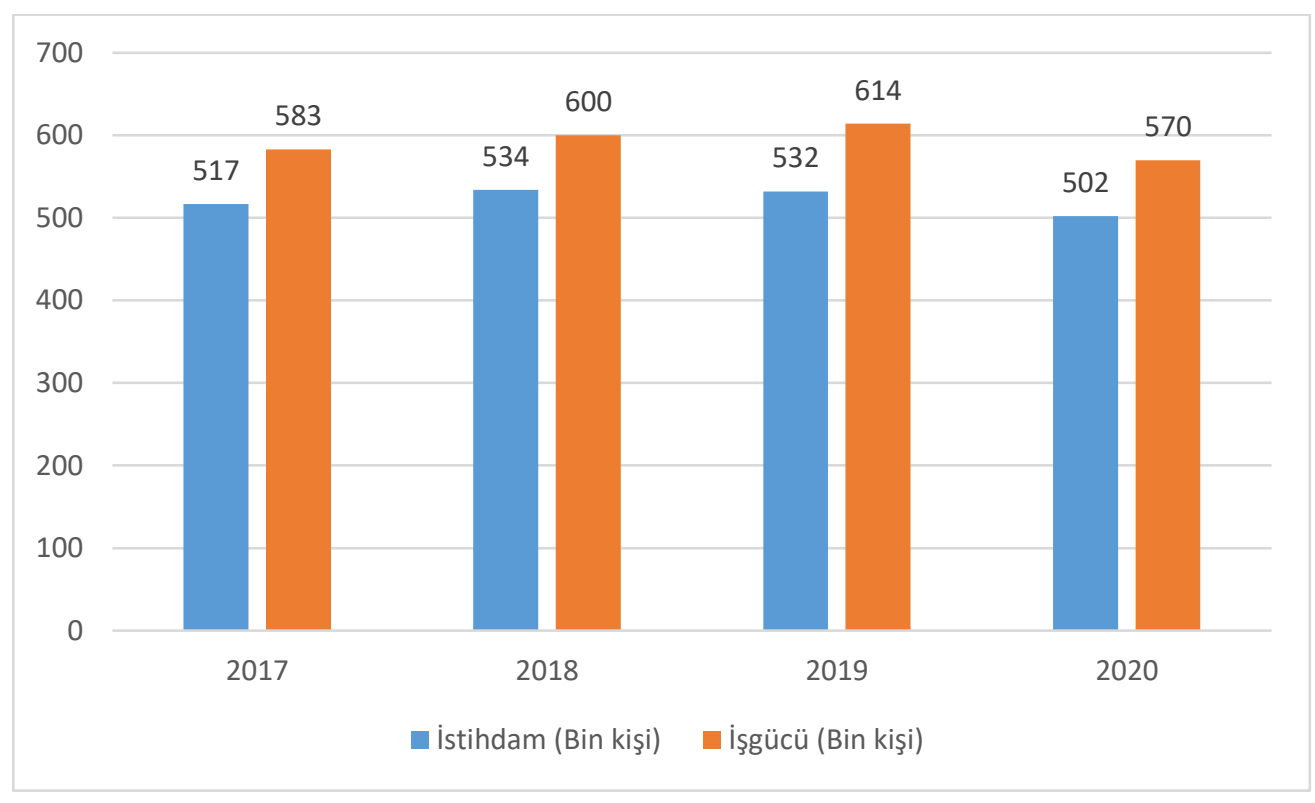

Kaynak: TÜiK, Bölgesel İstatistikler

Şekil 6.'da yer alan TR71 düzey 2 bölgesine ait veriler ele alındığında, son 4 yılda işgücü sayısında artış gözlemlenirken, 2019 yılında istihdam edilenlerin sayısı 534.000'den 532.000'e gerilerken, az da olsa işgücünde artış kaydedilmiştir. TR71 düzey 2 bölgesinde 2020 yılında hem istihdam hem de işgücü rakamlarının ciddi ölçüde azaldığı görülmektedir. Pandeminin etkisiyle istihdamda bir önceki yıla göre 30.000 kişi, işgücünde ise 44.000 kişi azalma yaşanmıştır. 
Şekil 7: TR71 Düzey 2 Bölgesinde İşsizlik, İşgücüne Katılım ve İstihdam Oranları (\%)

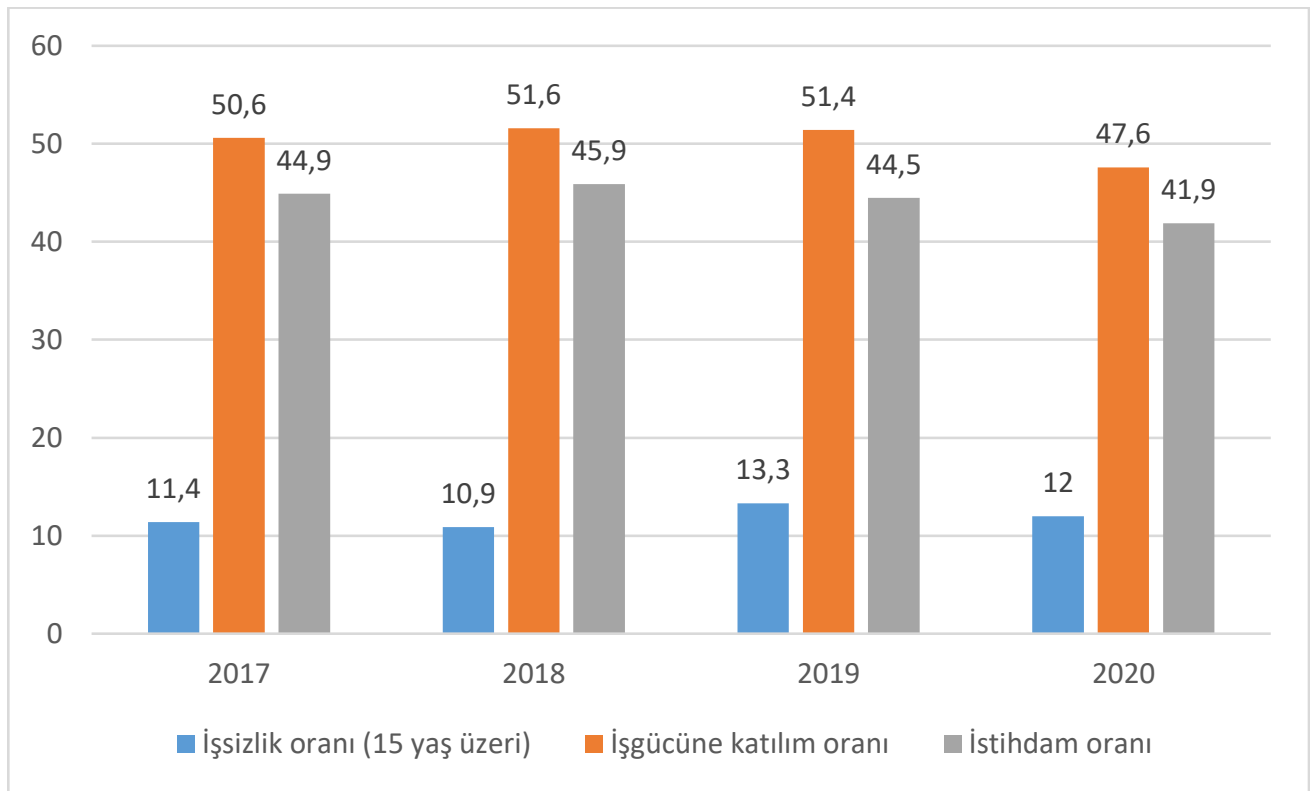

Kaynak: TÜiK, Bölgesel İstatistikler

TR71 Düzey 2 Bölgesinde, son dört yılda işgücüne katılım oranında sürekli düşüş yaşanırken, işsizlik oranında en yüksek artışın 2019'da olduğu d,kkat çekmektedir.nb2020 yılında ise TÜiK'in hesaplamalarda yaptığı düzenlemelerin etkisiyle işsizlik oranının \%12'ye kadar gerilediği görülmektedir. Buna rağmen en düşük işgücüne katılım ve istihdam oranlarının 2020 yııında yaşandığı dikkat çekmektedir. 2019 yıla ile kıyasladığımızda, 2020 yııında işgücüne katılım oranı yaklaşık 4 puan azalırken, istihdam oranı da yaklaşık 3 puan azalmıştır. 
Şekil 8. TR71 Düzey 2 Bölgesinde İktisadi Faaliyet Kollarına Göre İstihdam Edilenler (15+ Yaş)

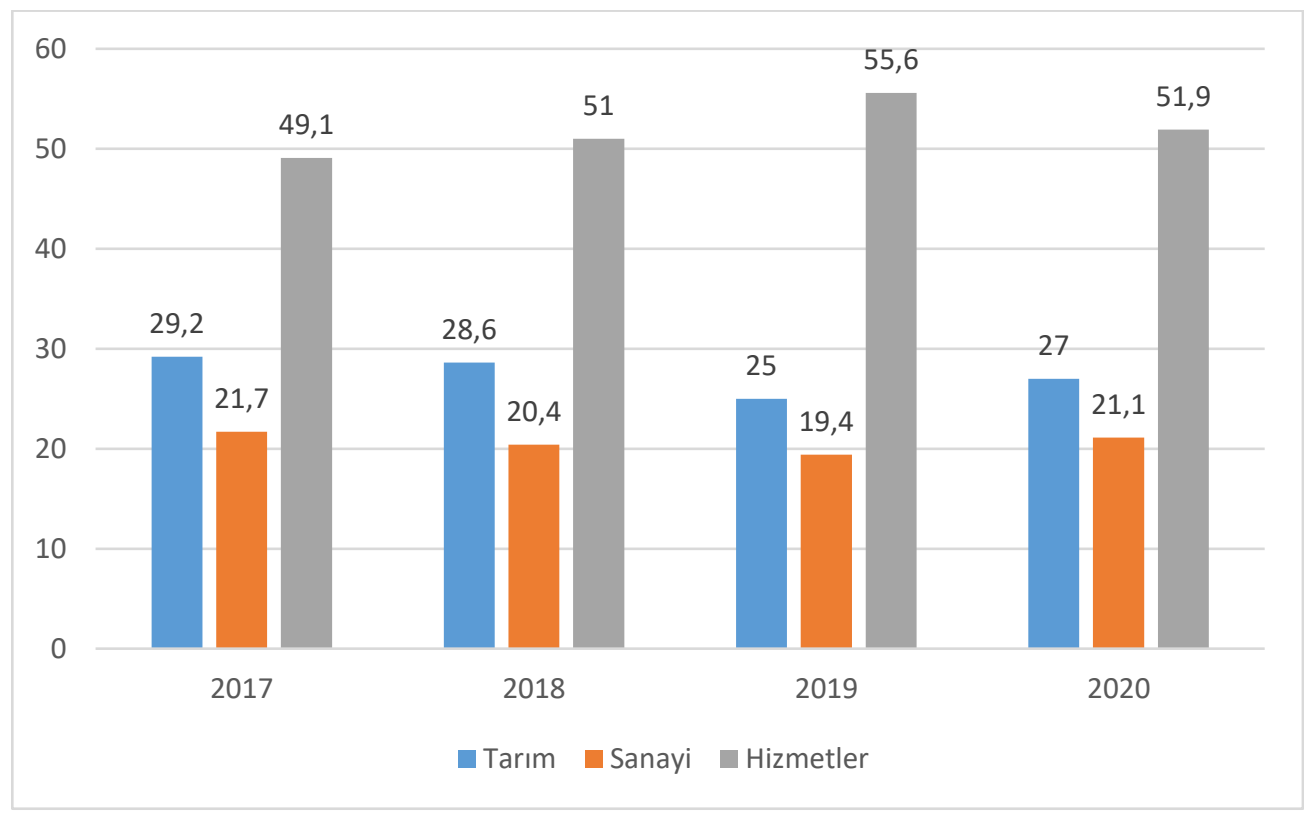

Kaynak: TÜiK, Bölgesel İstatistikler

2019'da iktisadi faaliyet kollarına göre istihdamın dağılımı dikkate alındığında bölgede istihdam edilenlerin yaklaşık \%25'i tarım sektöründe, \%19,4'ü sanayi sektöründe ve \%55,6'sı da hizmetler sektöründe çalıştığı görülmektedir. Bu oranlar bir önceki yıl ile karşılaştırıldığında tarım ve sanayinin payının azaldığı hizmetler sektörünün payının arttığı dikkat çekmektedir. Bu durum TR71 düzey 2 bölgesindede tarım sektöründen, hizmet ve sanayi sektörüne doğru bir geçişin olduğunu göstermektedir.

2020 yılında tarım ve sanayi sektörlerindeki istihdamda artış olduğu gözlemlenirken, pandeminin etkisiyle özellikle hizmet sektöründeki işyerlerinin çalışma saatlerinin ve şekillerinin kısıtlanmasının etkisiyle hizmet sektöründe çalışanların payında bir önceki yıla göre yaklaşık 4 puan azalma yaşanmıştır. 
Şekil 9. TR71 Düzey 2 Bölgesinde Cinsiyete Göre İşsizlik, İşgücüne Katılım ve İstihdam Oranları (\%)

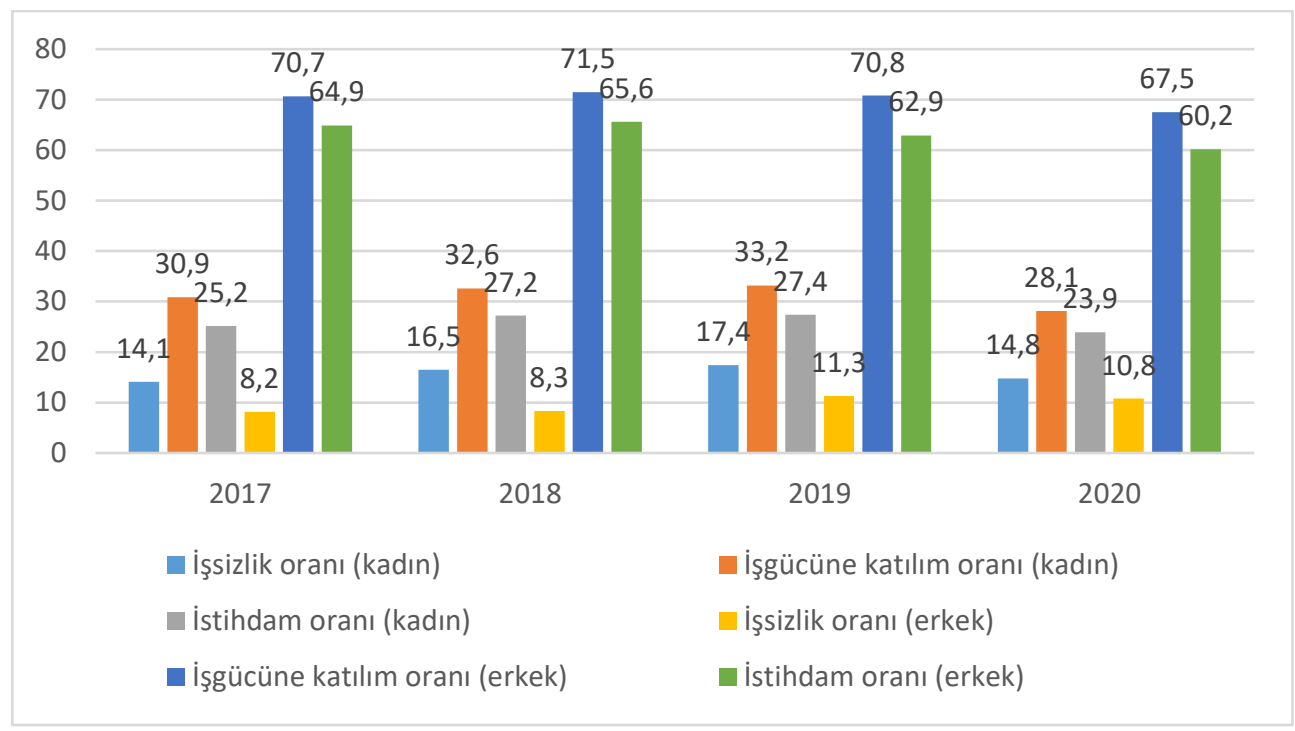

Kaynak: Tüik, Bölgesel İstatistikler

Şekil 9. incelendiğinde, TR71 düzey 2 bölgesinde kadın ve erkek arasında işgücüne katılım ve istihdam oranlarında önemli farklılıklar olduğu görülmektedir. TR71 düzey 2 bölgesinde 2020 yılı hariç kadın istihdam oranı ve işgücüne katılım oranlarında artış yaşandığı, ancak bölgedeki kadın istihdam oranı ve işgücüne katılım oranlarının Türkiye ortalamasının altında kaldığı görülmektedir. Özellikle 2020 yılında erkek istihdam oranında yaklaşık 3 puan, işgücüne katılım oranında ise yaklaşık 3,5 puan azalma yaşanırken, kadın istihdam oranında 3,5 puan, işgücüne katılım oranında ise yaklaşık 5 puan düşüş yaşanmıştır. Pandeminin işgücü ve istihdam üzerindeki olumsuz etkisinin kadınlar üzerinde daha çok hissedildiği grafikten açıkça görülmektedir.

Yapısal uyum politikaları, özellikle düşük gelire sahip olan kentli ailelerin satın alma güçlerini azaltmakta, tüm haneyi olumsuz etkileyen ekonomik baskı daha önce iş hayatında yer almayan hane üyelerini ev dışında iş aramaya yöneltmektedir. Ancak, arz edilen kadın emeğinin nitelikleri, bu emeği talep edecek olan işgücü pazarına uygun olmadığında veya emeğini arz etmek isteyen kadınlar bu pazarın çalışma koşullarını kabul edemediklerinde, işsizlik ortaya çıkmaktadır (Tan ve diğerleri, 2000, s. 122-123).

Birleşmiş Milletlerin yayınlamış olduğu raporda, Covid-19 salgınında kadınların karşılıksız bakım ev işlerine erkeklere oranla 3 kat daha fazla vakit ayırdığını, bu yüzden kadınların insana yaraşır işe erişimlerinin de kısıtlı olduğundan bahsetmektedir. Ayrıca küresel çapta 25-54 yaş aralığında yer alan erkeklerin aynı yaş gruptaki kadınlara göre daha fazla işgücüne eriştiğine değinmektedir (BM, 2020, s. 12-13). 
Şekil 10. Yaş Gruplarına Göre TR71 Düzey 2 Bölgesinde İşsizlik, İşgücüne Katılım ve İstihdam Oranları (\%)

\begin{tabular}{|c|c|c|c|c|}
\hline & 2017 & 2018 & 2019 & 2020 \\
\hline 15-24 yaş arası işsizlik oranı & 25,3 & 25,1 & 27,9 & 22,9 \\
\hline 25 yaş üzeri işsizlik oranı & 8,8 & 8,3 & 10,3 & 10,1 \\
\hline $\begin{array}{l}\text { 15-24 yaş grubu işgücüne } \\
\text { katılım oranı }\end{array}$ & 41,6 & 42 & 45,5 & 39,5 \\
\hline $\begin{array}{c}25 \text { yaş üzeri işgücüne katılım } \\
\text { oranı }\end{array}$ & 52,7 & 53,8 & 52,8 & 49,3 \\
\hline $\begin{array}{c}\text { 25-34 yaş grubu işgücüne } \\
\text { katılım oranı }\end{array}$ & 69,1 & 70 & 70,9 & 66,6 \\
\hline $\begin{array}{c}\text { 35-54 yaş grubu işgücüne } \\
\text { katılım oranı2 }\end{array}$ & 64,5 & 67 & 66,7 & 63 \\
\hline $\begin{array}{c}\text { - } 55 \text { yaş üzeri işgücüne katılım } \\
\text { oranı3 }\end{array}$ & 25,5 & 25,4 & 23 & 20,6 \\
\hline 15-24 yaş rubu istihdam oranı & 31 & 31,5 & 32,8 & 30,5 \\
\hline - 25 yaş üzeri istihdam oranı & 48,1 & 49,4 & 47,3 & 44,3 \\
\hline $\begin{array}{c}\text { 25-34 yaş grubu istihdam } \\
\text { oranı }\end{array}$ & 60,7 & 61,8 & 60,7 & 56,6 \\
\hline $\begin{array}{c}\text {-35-54 yaş grubu istihdam } \\
\text { oranı }\end{array}$ & 59,1 & 61,7 & 60,5 & 57,4 \\
\hline - 55 yaş üzeri istihdam oranı & 24,5 & 24,6 & 21,6 & 19,6 \\
\hline
\end{tabular}

Kaynak: TÜiK, Bölgesel İstatistikler

Şekil 10.'da yer alan veriler dikkate alındığında, TR71 düzey 2 bölgesinde özellikle işsizlik oranının hem 15-24 hem de 25 yaş üzerinde ciddi ölçüde artış gösterdiği, 2019 yılında 55 yaş üzeri hem istihdam oranı hem de işgücüne katılma oranında büyük bir düşüş yaşandığı görülmektedir. 2020 yılında her yaş grubunda istihdam ve işgücüne katılım oranlarının önemli ölçüde düşüş yaşanmıştır. Buna rağmen, özellikle 15-24 yaş grubundaki işsizlik oranı 5 puan birden azalma ortaya çıkmıştır.

\section{Türkiye ve TR71 Düzey 2 Bölgesi İşsizlik Ödeneği Başvuruları}

TR71 düzey 2 bölgesinde işKUR tarafından iş ve istihdam ile ilgili kurslar ve çalışmalar yürütülmektedir. Ancak bölge illerindeki iş ve istihdam sağlayacak sanayi ve işyeri 
yatırımlarının istenilen düzeyde olmaması bölgede işsizlik sorununun devam etmesine neden olmaktadır (AHIKA, 2016, s. 37).

Sigortalı işsizlere yasada belirtilen koşulları sağlamaları durumunda işsiz kaldıkları dönem için belirli süre ve miktarda yapılan ödemeye işsizlik ödeneği denir. İşsizlik ödeneğinin başvurana ödenebilmesi için sigortalı işsizlerin iş almaya hazır durumda olması şartı söz konusudur. İssizlik ödeneği başvurusu ile kişinin iş arayan kaydı yapılmakta veya güncellenmektedir. Böylece sigortalı işsizlerin danışmanlık, işe yerleştirme ve mesleki eğitim gibi hizmetlerden yararlanmaktadır (İş ve Meslek Danışmanlığı Derneği, 2011, s. 160-161).

Şekil 11. Türkiye'de 2020 Yılında İşsizlik Ödeneğine Başvuranların Cinsiyete Göre Dağılımı

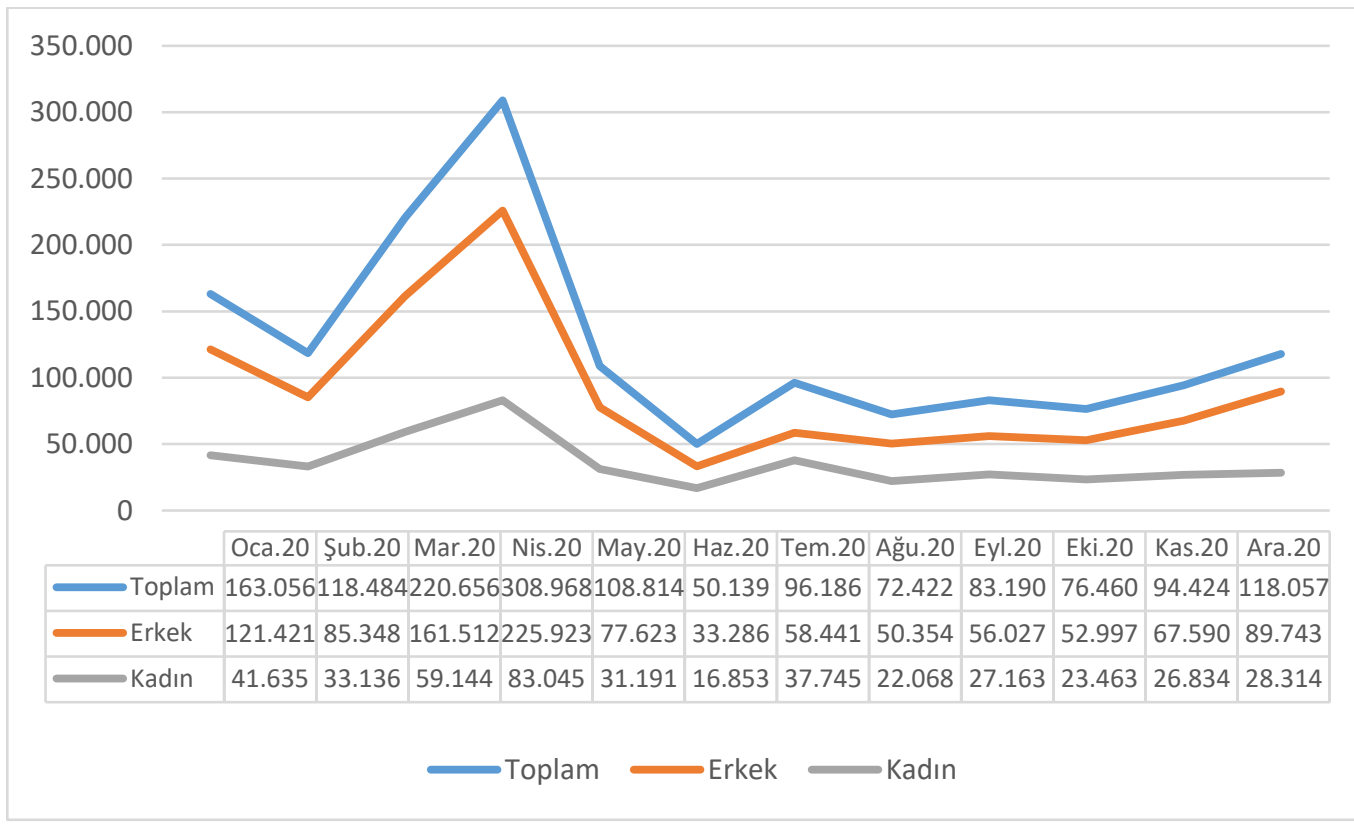

Kaynak: IŞKUR, Aylık İstatistikler

Şekil 11.'de yer alan işKUR verileri incelendiğinde, işsizlik ödeneğine yapılan başvuru sayısı Şubat 2020'de 118.484 iken Nisan 2020'de üç kat artarak 308.968 kişiye ulaştığı görülmektedir. Yaz döneminde hem kısıtlamaların azaltılması hem de turizm sezonunun açılmasıyla birlikte Haziran, Temmuz ve Ağustos aylarından işsizlik ödeneği başvurularının nispeten daha az olduğu dikkat çekmektedir. Vaka sayılarının artmasına paralel olarak kısıtlamaların artmasıyla birlikte Kasım ve Aralık aylarında başvurular da artış gerçekleşmiştir. 
Şekil 12. TR71 Düzey 2 Bölgesinde 2020 Yılında İşsizlik Ödeneğine Başvuranların Sayısı

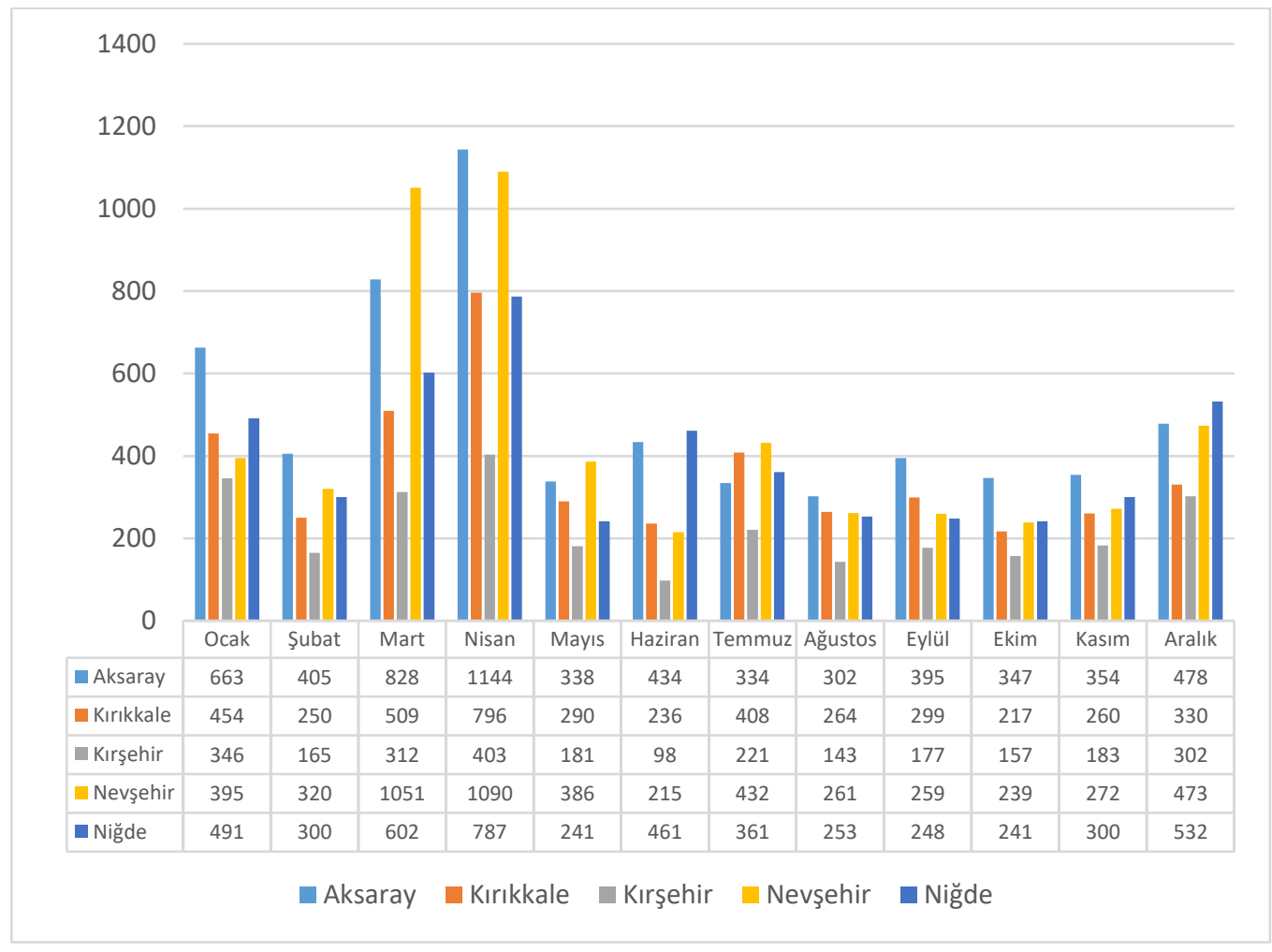

Kaynak: işKUR, Aylık İstatistikler

Şekil 12.'deki işsizlik ödeneği sayıları, TR71 düzey 2 bölgesinde özellikle Mart ve Nisan aylarında başvurunun fazla olduğunu, kısıtlamaların gevşetilmesiyle birlikte başvuruların da buna paralel olarak azaldığını göstermektedir. II bazında verileri ele aldığımızda, işsizlik ödeneğine başvuruların en yoğun olduğu Nisan ayında, Aksaray iline ait başvuruların ilk sırada, Nevşehir'deki başvuranların sayısının ikinci sırada ve Kırıkkale'deki başvuranların sayısının üçüncü sırada olduğu görülmektedir.

\section{Sonuç}

Covid-19 salgınına tüm dünyanın hazırlıksız yakalandı̆̆ı bir gerçektir. Gelişmiş Avrupa ülkelerinin bazıları çok katı yasaklar uygulamalarına rağmen virüsün hızla yayılmasını ve vefat sayılarının artmasının önüne geçememektedir. Virüsün insandan insana çok hızlı bir şekilde bulaşması, ülkeleri sosyal mesafe kavramına vurgu yaparak önlemlerini de buna uygun almalarına mecbur bırakmıştır. Bu kapsamda bazı ülkelerde hizmet sektöründe kilit rol oynayan alışveriş merkezleri, cafe ve restoranlar, spor salonları, sinema ve tiyatro salonları ve 
güzellik merkezleri belli bir süre kapatılmış, bazı ülkelerde ise çalışma saatlerine sınırlama getirilmiştir. Alınan bu önlemler ülkelerin işgücü piyasalarını da olumsuz etkilemiştir.

TR71 bölgesinde hizmet sektörünün öne çıktığı ve Covid-19 salgınının da ağırlıklı olarak hizmet sektörünü etkilediği için çalışmada TR71 düzey 2 bölgesi incelenmiştir. Hem Türkiye hem de TR71 düzey 2 bölgesine ait işgücü verileri incelendiğinde, pandeminin olumsuz etkileri özellikle işgücüne katılım oranları ve istihdam oranlarında açıkça görülmektedir. 2020 yılında hem istihdam hem de işgücü rakamlarının ciddi ölçüde azaldığı görülmektedir. Pandeminin etkisiyle istihdamda bir önceki yıla göre 30.000 kişi, işgücünde ise 44.000 kişi azalma yaşanmıştır. TR71 Düzey 2 Bölgesinde, en düşük işgücüne katılım ve istihdam oranlarının 2020 yılında yaşandığı dikkat çekmektedir. 2019 yıla ile kıyasladığımızda, 2020 yıında işgücüne katılım oranı yaklaşık 4 puan azalırken, istihdam oranı da yaklaşık 3 puan azalmıştır.

TR71 düzey 2 bölgesinde 2020 yılında tarım ve sanayi sektörlerindeki istihdamda artış olduğu gözlemlenirken, pandeminin etkisiyle özellikle hizmet sektöründeki işyerlerinin çalışma saatlerinin ve şekillerinin kısıtlanmasının etkisiyle hizmet sektöründe çalışanların payında bir önceki yıla göre yaklaşık 4 puan azalma yaşanmıştır. Buna ek olarak pandeminin kadınlar üzerindeki olumsuz etkisinin daha fazla olduğu da dikkat çekmektedir. Ayrıca pandemi döneminde TR71 düzey 2 bölgesinde özellikle Mart ve Nisan aylarında başvurunun fazla olduğunu, kısıtlamaların gevşetilmesiyle birlikte başvuruların da buna paralel olarak azaldığını göstermektedir.

Pandemi döneminde tam kapanma uygulamasından dolayı çoğu ülkede İşyerlerinin kapanması sebebiyle hem toplam talepte daralma yaşanmış hem de özellikle hizmet sektöründe çalışanların büyük bir kısmı işini kaybetmiştir. Bu bağlamda küresel çapta azalan toplam talebe karşı önlem alabilmek ve işsiz kalanlara geçici de olsa nakdi ödeme yapabilmek için, uluslararası kuruluşlar ülkelere yönelik yardım ve destek programları uygulamaya başlamıştır.

Hükümetlerin uygulamaya koyduğu politikaların başlangıçta başarı oranı yüksekti ancak bu politikalar reel sektörü olumsuz etkilemiş ve küresel ekonomide belirsizlik yaratmıştır. Bu küresel belirsizlik Türkiye ekonomisinde de büyük bir tahribata yol açmıştır. Covid-19 salgınının yarattığı tahribat dikkate alındığında, Türkiye'nin istihdamla ilgili yapısal reformları hayata geçirmesi ve sürekli artan genç işsizliğe yönelik önemli adımların hem bölgesel hem de ulusal düzeyde uygulanması gerekmektedir. Bu dönemde dijitalleşmenin çoğu sektördeki önemi giderek arttı̆̆ı için, bireylerin çevrimiçi becerilerinin geliştirilmesine yönelik eğitimlere öncelik verilmelidir. Ayrıca pandeminin özellikle kadın istihdamı üzerindeki olumsuz etkileri göz önünde bulundurulduğunda, Türkiye'de kadın girişimci destekleri arttırımalı ve uzaktan çalışma modeli kadınlar için kalıcı hale getirilmelidir. 


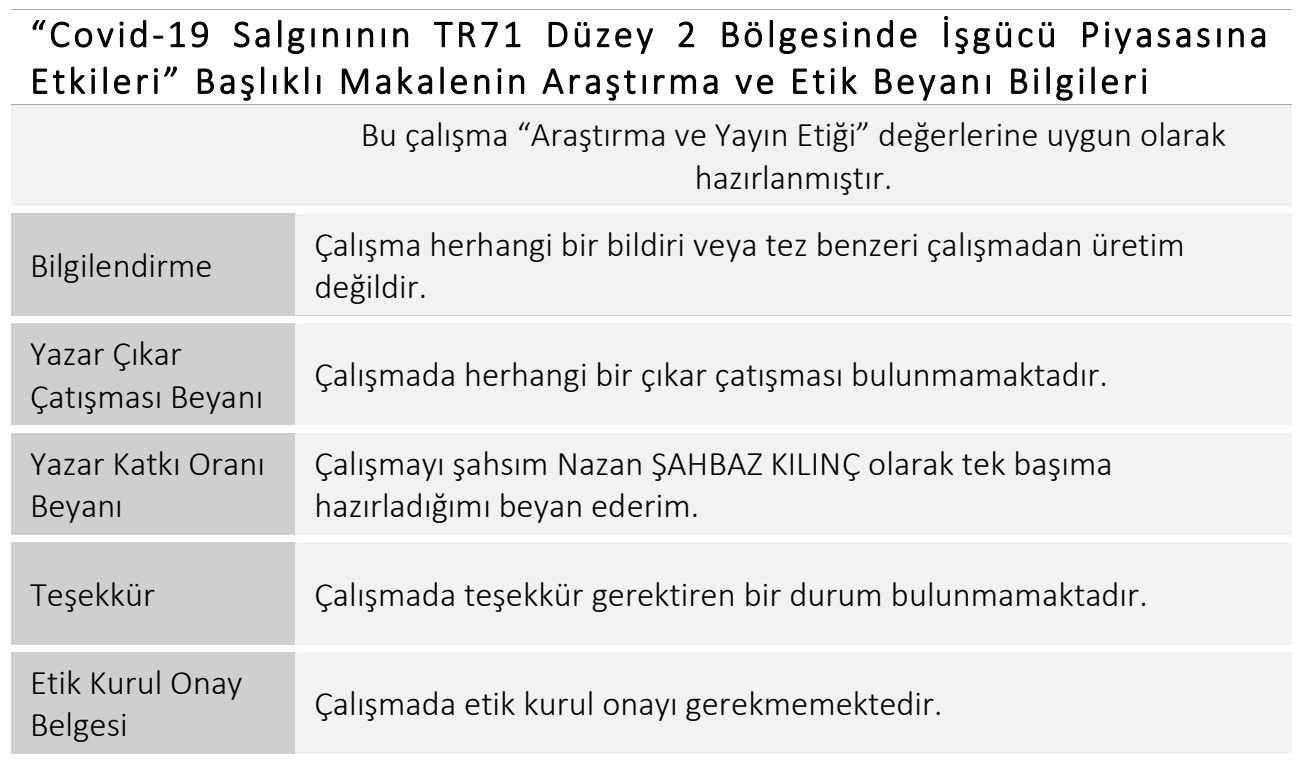

\section{Kaynakça}

AVM'lerdeki kafe ve restoranlar kısıtlama kapsamında, Kasım 18, 2020 tarihinde http://www.aa.com.tr/tr/turkiye/avmlerdeki-kafe-ve-restoranlar-da-kisitlamakapsamında/2047984 adresinden alındı.

AHIKA, TR71 Düzey 2 Bölgesi Bölge Planı 2014-2023, Haizran 20, 2021 tarihinde http://ahika.gov.tr/assets/ilgilidosyalar/2014-2023-Taslak-Bolge-Plani-Versiyon-

3.pdf adresinden alındı.

Hedin, T. J., Schnorr, G., \& Von Wachter, T. (2020). An Analysis of Unemployment Insurance Claims in California During the Covid-19 Pandemic. California Policy Lab, Temmuz 27, 2021 tarihinde Dec-21st-Analysis-of-CA-UI-Claims-during-the-COVID-19Pandemic.pdf adresinden alındı.

Birleşmiş Milletler (BM). (2020). Policy Brief: The Impact of Covid-19 on Women. Temmuz 25, $2020 \quad$ tarihinde https://www.unwomen.org/media/headquarters /attachments/sections/library/publications/2020/policy-brief-the-impact-of-covid19-on-women-tr.pdf?la=en\&vs=2900 adresinden alındı.

Bulut, R. \& Pınar, Ç. (2020). Covid-19 Pandemisi Döneminde Türkiye'de İstihdam ve İşsizlik. Oğuzhan Sosyal Bilimler Dergisi, 2(2), 217-225.

Cortes, G. M., \& Forsythe, E. (2020). The Heterogeneous Labor Market Impacts of the Covid19 Pandemic, Available at SSRN 3634715. 
DiKA (2020). Dicle Kalkınma Ajansı. TRC3 Bölgesinde ,Covid-19 Salgınının Ekonomik ve Sosyal Etkileri Araştırma Raporu. Temmuz 23, 2021 tarihinde trc3-bolgesinde-covid-19salgininin-ekonomik-ve-sosyal-etkileri-arastirma-raporu.pdf adresinden alındı.

Kahn, L. B., Lange, F., \& Wiczer, D. G. (2020). Labor Demand in the Time of Covid-19: Evidence from Vacancy Postings and UI Claims, No 27061, NBER Working Papers from National Bureau of Economic Research, Inc.

Hall, R. E., \& Kudlyak, M. (2020). Unemployed With Jobs and Without Jobs, No. 27886, National Bureau of Economic Research.

T.C Kalkınma Bakanlığı. (2014). İstihdam ve Çalışma Hayatı. Temmuz 25, 2021 tarihinde 10_IstihdamveCalismaHayati.pdf adresinden alındı.

Kara, E. (2020). Covid-19 Pandemisi: İşgücü Üzerindeki Etkileri ve İstihdam Tedbirleri. Avrasya Sosyal ve Ekonomi Araştırmaları Dergisi, 7(5), 269-282.

Koca, D. (2020). Türkiye'de İşücü Piyasasının Boyutları ve Covid-19 Döneminin İsgücü Piyasasına Etkileri. Sosyal Çalışma Dergisi, 4(2), 1-15.

ILO (International Labour Orgnization). (2020). Covid-19: Public employment services and labour market policy responses, Aralık 18, 2020 tarihinde eas/https://www.ilo.org/emppolicy/arcovid/WCMS_753404/lang--en/index.htm adresinden alındı.

IMF, COVID-19 Financial Assistance and Debt Service Relief, Eylül 12, 2020 tarihinde https://www.imf.org/en/Topics/imfand-covid19/COVID-Lending-Tracker adresinden alındı.

İ̧ ve Meslek Danışmanlığı Derneği, Temmuz 25, 2021 tarihinde https://semper.sdu.edu.tr/DpsDokumanlar/files/IMDEgitimKitabi.pdf, adresinden alındı.

IŞKUR. (2020). Bölgesel İstatistikler.

OECD. (2020). Delineating Functional Areas in All Territories, Temmuz, 262021 tarihinde http://doi.org./10.1787/07970966-en adresinden alındı.

Progem (Proje Geliştirme Merkezi). (2013). TR71 Düzey 2 Bölgesi Sosyal Yapıda Mevcut Durum ve 2014-2023 Yılları Stratejileri ve Hedefleri Raporu.

Su, C. W., Dai, K., Ullah, S., \& Andlib, Z. (2021). Covid-19 Pandemic and Unemployment dynamics in European Economies. Economic Research, Temmuz 30, 2021 tarihinde DOI: 10.1080/1331677X.2021.1912627 adresinden alındı.

Trend Analizi, Covıd-19 Salgınının Küresel Ekonomi ve Jeopolitikaya Etkileri, Ocak 15, 2021 tarihindehttps://thinktech.stm.com.tr/uploads/raporlar/pdf/852020102559263_st m_covid_19_salgininin_kuresel_ekonomi.pdf adresinden alındı.

Tan, M., Ecevit, Y., \& Üşür, S. S. (2000). Kadın-Erkek Eşitliğine Doğru Yürüyüş: Eğitim, Çalışma Yaşamı ve Siyaset. İstanbul, (Yayın No. TÜSiAD-T/2000-12/290). 
TÜik. (2020). Bölgesel İstatistikler, Bölgesel İstatistikler (tuik.gov.tr) adresinden alındı.

TÜiK. (2021). Mart 25, 2021 tarihinde http://tuikweb.tuik.gov.tr/HbPrint.do?id=37486 adresinden alındı.

Uysal, G., Mutluay, H. \& Şahin M. C. (2020). COVID-19 Pandemisinin İşgücü Piyasasında Yarattığı Tahribat Nasıl Takip Edilmeli?. İstanbul Politikalar Merkezi, Sabancı Üniversitesi, IPM-Mercator Politika Notu. 


\title{
Measuring the Efficiency of Health System Developments in the Covid 19 Pandemic: A Study on the G-20
}

\author{
Nazan ŞAHBAZ KILINÇ
}

\section{Extended Abstract}

\begin{abstract}
Although the Covid-19 epidemic emerged as a health crisis worldwide, this epidemic turned into a global economic crisis in the following period, and it is not known exactly how long this crisis will last. In the study, it was explained with the help of tables and graphs how the Covid19 crisis, whose effects were deeply felt all over the world and turned into an economic crisis with the health crisis, affected the labor market both in Turkey and in the TR71 region. Additionally the study differs from other studies because it examines Turkey and TR71 comparatively. When the data used in the study are examined, the decreases in labor force participation and employment rates are clearly seen. In addition, during the pandemic period, applications for unemployment benefits intensified both in Turkey and in the TR71 level 2 region, especially in April 2020.
\end{abstract}

The effects of hte Covid-19 crisis on the labor market both in Turkey and in the TR71 level 2 region are explained with the help of tables and graphs using data on unemployment, labor force participation, employment rates and unemployment benefits. When the labor market data of both Turkey and TR71 level 2 regions are considered, the negative effects of the pandemic are clearly seen especially in the labor force participation and employment rates. In addition, it is noteworthy that during the pandemic period, applications for unemployment benefits intensified both in Turkey and in the TR71 level 2 region. In the first part of the study, the studies on the effects of Covid-19 on employment are summarized, in the second part, the employment structure and workforce in teh TR71 level 2 region are discussed in detail. In the third part, the development of employment and labor force indicators in Turkey, in the fourth part, the employment structure and workforce developments by gender anda ge groups in Turkey and the TR71 level 2 region and in the fifth part, the unemployment benefit applications for Turkey and the TR71 level 2 region are demonstrated with the help of graphs. In the last part, a general evaluation has been made.

Since the service sector is prominent in the TR71 region and the Covid-19 epidemic predominantly affects the service sector, the TR71 level 2 region has been examined in the study. When the labor force data of both Turkey and TR71 level 2 regions are examined, the negative effects of the pandemic are clearly seen especially in the labor force participation rates and employment rates. It is observed that both employment and labor force figures 
have decreased significantly in 2020. With the effect of the pandemic, there was a decrease of 30,000 people in employment and 44,000 people in the workforce compared to the previous year. It is noteworthy that in the TR71 Level 2 Region, the lowest labor force participation and employment rates were experienced in 2020. While an increase was observed in employment in the agriculture and industry sectors in the TR71 level 2 region in 2020, the share of those working in the service sector decreased by approximately 4 points compared to the previous year, with the effect of the pandemic, especially the restriction of working hours and forms of workplaces in the service sector. It is also noteworthy that the negative impact of the pandemic on women is more. It also shows that during the pandemic period, the number of applications in the TR71 level 2 region was high, especially in March and April, and the applications decreased with the reduction of restrictions.

Due to the full closure practice during the pandemic period, due to the closure of workplaces in most countries, there was a contraction in total demand and a large part of the employees, especially in the service sector, lost their jobs. The success rate of the policies implemented by the governments was high at the beginning, but these policies adversely affected the real sector and created uncertainty in the global economy. This global uncertainty has also caused great damage to the Turkish economy. Considering the devastation caused by the Covid-19 epidemic, Turkey needs to implement structural reforms related to employment and take important steps towards ever-increasing youth unemployment at both regional and national levels. As the importance of digitalization in most sectors is increasing in this period, trainings for the development of individuals' online skills should be given priority. 